University of Nebraska - Lincoln

DigitalCommons@University of Nebraska - Lincoln

1991

\title{
Climate and Vegetation In Central North America: Natural Patterns and Human Alterations
}

John A. Harrington Jr

Indiana State University

Jay R. Harman

Michigan State University

Follow this and additional works at: https://digitalcommons.unl.edu/greatplainsquarterly

Part of the Other International and Area Studies Commons

Harrington, John A. Jr and Harman, Jay R., "Climate and Vegetation In Central North America: Natural Patterns and Human Alterations" (1991). Great Plains Quarterly. 592.

https://digitalcommons.unl.edu/greatplainsquarterly/592

This Article is brought to you for free and open access by the Great Plains Studies, Center for at DigitalCommons@University of Nebraska - Lincoln. It has been accepted for inclusion in Great Plains Quarterly by an authorized administrator of DigitalCommons@University of Nebraska - Lincoln. 


\title{
CLIMATE AND VEGETATION IN CENTRAL NORTH AMERICA
}

\author{
NATURAL PATTERNS AND HUMAN ALTERATIONS
}

JOHN A. HARRINGTON, JR. AND JAY R. HARMAN

The he characteristic patterns of climate and natural vegetation in central North America are strongly interrelated and result from an atmospheric circulation system that responds to both global and continental scale mechanisms. Climatic patterns arise in the region between the Rocky Mountains and the Great Lakes or Mississippi River from the interactions between two major components of the global atmospheric circulation system, the tropical Hadley Cell and the extratropical, upper-level Westerlies. The Westerlies, particularly, are influenced and steered by thermal inequalities over the earth's surface as well as by terrain barriers such as the Rocky Mountain Cordillera. In addition, both the Hadley Cell and the Westerlies shift north and south on an annual cycle.

An associate professor of geography and geology at Indiana State University, John A. Harrington, Jr., has published many climatological studies of the midcontinent region of North America. Jay R. Harman, professor of geography at Michigan State University, has published studies of climatology and soil and vegetation distribution.

[GPQ 11 (Spring 1991): 103-112]
To some extent, natural vegetation in the midcontinent mirrors the regional climate in terms of both species composition and plant structure. For example there are three major biomes along a west-to-east gradient of increasing moisture availability. Grasslands associated with semiarid climates of the Great Plains give way to a transitional zone of oak savanna, sometimes called the prairie-forest ecotone, and finally to areas of predominantly deciduous forest in more humid climates to the east.

Both the vegetation and climate of the midcontinent vary over time. Climate system fluctuations over time scales ranging from periods of several days to several years to the millennia between glacial and interglacial periods change the patterns and frequencies of surface weather types. These climatic fluctuations affect the patterns and intensity of plant stresses and change the vegetative cover, particularly in grassland environments of the midcontinent where a range of natural vegetation, rather than a single climax type, exists in response to a number of climatic states. ${ }^{1}$

This paper will summarize the climatic controls and natural vegetation of the midcontinent region and will describe natural climatic variation and the associated vegetative re- 
sponse. Because human adaptations associated with settlement and the establishment of economic activities have had significant and longreaching impacts on native vegetation, this paper will also assess the ways forest clearing, sodbusting, cattle ranching, and fire prevention activities have altered vegetation patterns, leaving only scarce remnants of the primeval natural cover.

\section{AtMOSPHERIC CiRCULATION AND THE Regional Climate}

The earth's atmospheric circulation system primarily determines midcontinent climate. Latitudinal differences in energy set in motion a global wind system that partially offsets an equator-to-pole imbalance in radiation receipts and surface temperatures. This circulation system contains two major components, the Hadley Cell, a vertical and north-south oriented cell associated with tropical areas, and the midlatitude Westerlies, an extratropical circumpolar swirl of primarily west-to-east winds. ${ }^{2}$ The transition area between these two circulation components shifts north and south across the midcontinent throughout the course of the year. During the summer months the Westerlies are restricted to the northernmost sections of the midcontinent. In July and August, the Polar Front Jet Stream, the central core of the Westerlies, is commonly found between $45^{\circ} \mathrm{N}$ and $50^{\circ} \mathrm{N}$. As the cool season progresses, the circumpolar Westerlies expand southward and influence more and more of the midcontinent, until by the middle of winter the entire area is under the influence of the upper-level Westerlies and their associated jet stream(s). The boundary zone between the Hadley Cell and the Westerlies migrates slowly northward during the spring. By late June, the annual cycle is complete and a majority of the midcontinent is again feeling the direct influence of tropical air streams and the Hadley Cell.

These annual changes in the global atmospheric circulation system produce midcontinent weather and climatic conditions that exhibit strong seasonal differences. Outbreaks of exceptionally cold Arctic air, blizzards, severe thunderstorms and tornadoes, hail, dust storms, searing heat, and torrential rains are all characteristic aspects of this annual suite of weather types. The magnitudes and frequencies of these important weather events vary from one year to the next in response to shifting patterns in the global circulation.

The following discussion focuses on the warm season in order to emphasize the weather and climatic conditions that correspond with the timing of important plant processes such as growth, reproduction, and seedling survival. Warm season environmental conditions greatly influence agriculture, an activity of considerable economic and cultural importance in the midcontinent.

Throughout nearly all of the midcontinent, the predominant native vegetation is dormant during the winter with its freezing temperatures. During the warm season, however, the several aspects of global atmospheric circulation combine to produce weather conditions that stress growing plants and regulate both natural vegetation and agriculture. The Westerlies, the associated Polar Front Jet Stream, and the associated surface storm track dominate northern sections of the midcontinent. In midsummer these features are aligned with the prairieforest ecotone from central Canada into western sections of the Great Lakes region. ${ }^{3}$

In contrast, the descending branch of the Hadley circulation controls climate in the southern and central midcontinent. This subsident motion produces the "Bermuda High," a large, semipermanent surface high pressure cell centered over eastern sections of the Atlantic Ocean. Surface wind flow on the west side of this system is predominantly southerly. ${ }^{4}$ This pattern pumps warm, moist air northward from the western Gulf of Mexico into eastern sections of the midcontinent. Across western sections of the Great Plains, however, the northward flow originates over the warm, dry regions of West Texas and Mexico. Corcoran has suggested that the orientation of the Westerlies and resultant vertical motions in the atmosphere influence these surface air streams; 
drier air subsiding from middle levels of the troposphere further enhances the west-to-east contrast in atmospheric moisture. ${ }^{5}$ The combined influence results in a distinct gradient in atmospheric moisture, warm season rainfall totals, and associated plant moisture stresses. Changes in structure and floristics of natural vegetation parallel precipitation increases and potential evapotranspiration stress from west to east.

\section{The Regional Climate AND \\ ENVIRONMENTAL GRADIENTS}

Scientists have long recognized that moisture conditions are a primary regulator of regional vegetative cover, but our understanding of climate-vegetation relationships has improved markedly since Hare asserted that "climate is the ultimate ecological control." An important consideration is the scale of the investigation. Gleason postulated that plants react as individuals to environmental stresses and that the cooccurrence of plants in recognizable communities is a result of random processes. Site factors, such as soil, fire regime, and biotic interactions "determine local-scale patterning" whereas "[c]limate can be considered as a firstorder constraint on range limits." ${ }^{1}$ Much of the recent advance in understanding continentalscale climate-vegetation relationships has resulted from investigations of climate system dynamics, specifically of the processes whereby atmospheric motions generate the surface conditions that limit vegetation distributions by stressing plants. Earlier works had relied only on the implications from statistical and spatial correlations between surface climatic data and the boundaries of major plant formations.

Naturalists who drew inferences from the spatial correspondence between plant formation boundaries and mapped isolines of climatic statistics, such as mean annual rainfall, provide some of the earliest insights into the influence of climate on vegetation. One particularly striking boundary is the transition zone marking the change in dominant vegetative structure from grass through savanna to forest. Currently the prairie-forest ecotone arcs southeastward from central Canada across Minnesota, Wisconsin, northern Illinois, and into Indiana. Another arcuate boundary can be traced north and eastward from the western Gulf of Mexico across east Texas, eastern Oklahoma, Missouri, and Illinois. The two ecotonal arcs merge in northwestern Indiana. The area between and west of these ecotones is the Prairie Peninsula, a wedge of upland prairie grasslands that seemingly penetrates eastward into the deciduous forests. ${ }^{7}$

Transeau recognized that patterns of annual precipitation and evaporation ratios corresponded with patterns of plant distribution. ${ }^{8}$ Grasslands predominated where potential evaporation was greater than precipitation, whereas forests were found where the ratio was reversed. This statistical and spatial relationship held for the Prairie Peninsula, which he believed could be accounted for by a rate of evaporation higher than precipitation. The surrounding forests occur in areas of higher precipitation. Transeau and others have demonstrated a number of other correlations between isolines of surface climatic conditions and the prairie-forest ecotone. "Midsummer relative humidity is certainly lower in the Peninsula than north or south of it," observed Transeau. ${ }^{9}$

In addition, Borchert identified spatial correlations between the margins of the central North American grassland region and positive temperature deviations during drought years, below normal precipitation during major drought years, the number of rain days in July and $\mathrm{Au}$ gust, and the amount of winter snowfall on the northeastern boundary and the amount of winter season precipitation on the southeastern boundary. All his observations implied that more moisture was available to plants in the wooded area than in the Prairie Peninsula. Mather used Thornthwaite water budget concepts, essentially a hydrologic accounting system, to demonstrate an association between a statistically derived climatic parameter that estimates crop moisture status, the moisture index, and the major midcontinent vegetation types. Manogaran used this same water budget approach to demonstrate a good spatial relationship between 
soil moisture deficit and the northeastern boundary of the Prairie Peninsula and to match isolines of water surplus and the moisture index with the peninsula's western and southeastern boundaries. ${ }^{10}$

As our understanding of the mechanics of the atmospheric circulation system has improved, fresh and more thorough studies of vegetation-climate relationships have been undertaken. One fruitful area of research has focused on the relationship between upper-level wind flow patterns, the associated vertical motions, and resultant climatic responses. This new orientation, made possible by advances in our understanding of upper-atmospheric meteorology, particularly when combined with computer-based models, dramatically altered the fields of both meteorology and climatology, spawning what Neilson has called "the New Meteorology" in biogeographic investigations. ${ }^{11}$

One aspect of this process-oriented approach to climatic studies was the development and use of the air mass concept in plant-climate studies. An air mass, a relatively homogeneous body of near surface air with temperature and moisture referable to a particular source area, is produced by air subsiding from the controlling upper-level circulation; polar air masses are the result of subsidence from the Westerlies whereas tropical air masses result from downward vertical motions at the poleward margin of the Hadley Cell. Borchert demonstrated that maritime polar air masses, moving over the Rocky Mountain Cordillera from a Pacific Ocean source region, are most frequent over grassland areas during the warm season. These modified Pacific air masses are both warmed and dried by passage over the mountains. Bryson found similar results in his thorough study of North American air mass regions. ${ }^{12}$ Patterns of frequently occurring warm season air masses demonstrated spatial correlation with major plant formations. Maritime tropical air flowing northward from western sections of the Gulf of Mexico occupies areas of deciduous forests in southeastern sections of the midcontinent, cooler continental polar air is more common in the forested areas north and east of the Prairie Peninsula, and modified $\mathrm{Pa}$ - cific air influences the grassland region.

Subsequently other researchers have examined linkages between flow patterns in the Westerlies, the associated vertical motions, and the resultant surface weather patterns. Surface weather features, including moisture, temperature, and wind, are generated and steered by the flow pattern aloft. These conditions then apparently limit the distribution of plants according to the differential response of various species to stress. Harrington suggested that the most frequent pattern of summer upper-level flow across the northern midcontinent helped determine the distribution of surface moisture and thus reinforced the location of the prairieforest ecotone. Corcoran, working on the prairie-forest ecotone in the southeastern midcontinent, found that, in grassland areas, subsidence of dry air from middle levels of the troposphere frequently diluted the warm, moist air moving northward from the Gulf of Mexico while forested areas farther to the east usually received their moist air undiluted. ${ }^{13}$ Thus both Harrington and Corcoran have identified a connection between the global atmospheric circulation system and gradients in surface conditions that help explain the geographic distribution of plants.

By combining detailed knowledge of the dominant atmospheric motions with knowledge of how the resultant environmental conditions affect plants, these recent investigations have clarified the linkages between isolines of climatic variables and the patterns of natural vegetation distribution.

\section{The Pattern of Natural Vegetation}

Regional climatic patterns strongly affect the broad-scale distribution of vegetation in midcontinent North America, but other environmental factors, such as disturbance frequency, soil type, landform position, and local vegetational history, influence distribution as well. Thus the vegetation at any given site reflects both climatic influences and the intricacies of the local environment. Pollen studies indicate that the current dominant species of vegetation 
in central North America have responded differently to the climatic changes of the Pleistocene Epoch, which began about 1.0-1.5 million years ago. These pollen-based studies indicate that, while some individual species may still be responding to changes in climate with minor adjustments in geographic distribution, the current climate-vegetation relationships were established around 2000 years before the present. ${ }^{14}$ Thus the following discussion underscores the role of climate, and particularly moisture availability and plant responses to moisture stress, in regulating the broad-scale patterns of the dominant species of vegetation.

Before the wide-scale disturbance associated with Euro-American settlement, three major vegetation formations occupied the midcontinent: grasslands, savanna, and forests. Subdivisions of the central North American grassland included 1) the short grass or bunch grass steppes of the western High Plains, extending north into Saskatchewan, 2) an area of mixed grass prairie that extends from central Texas northward across western Oklahoma, central Kansas, central Nebraska, eastern sections of the Dakotas, and into Canada, and 3) the tall grass prairies in eastern sections of Oklahoma, Kansas, and Nebraska, western parts of Iowa and Minnesota, and in the Prairie Peninsula.

The eastern margin of this vast grassland region, the prairie-forest ecotone, was marked by a variety of vegetation types. Flood plain forests occupied the alluvial soils adjacent to major stream courses, whereas oak savannas grew in areas of coarse textured soils on the intervening uplands. Farther north, aspen parklands separated grassland from boreal evergreen forest in Canada.

In the United States, oak forests are found to the northeast and southeast of the prairie grasslands and their border zone. Other deciduous trees become increasingly important further eastward through Indiana as moisture supplies increase and environmental stresses decrease. Mixed deciduous and coniferous forests are found further to the northeast and southeast.

The Grasslands. Variations within the grassland region of the midcontinent are a function of both environmental controls and individual species tolerances. Climate and disturbance, particularly fire and grazing, are commonly cited as the two most important environmental controls on a regional basis, while topography, soils, and seed source availability account for most local variation. Grass species apparently migrated into the midcontinent from several directions, including the western intermountain basins, the southeastern coastal plains, and the southwestern desert basins of the United States. ${ }^{15}$

Varying migration rates, prevailing climatic gradients (including year-to-year fluctuations), and differences in individual species' ability to compete for scarce resources such as water account for considerable place-to-place variation in the plant species present across the midcontinent. North-to-south gradients in temperature, day length, and precipitation influenced the natural distribution of grass species and also influence the location of the dominant agricultural crops of today. Spring wheat, rye, oats, and barley are grown in northern areas, whereas corn dominates in central sections, and winter wheat and grain sorghum are more common southward. The north-south gradient also affects photosynthesis. The percentage of $\mathrm{C}_{4}$ plants, species that use a photosynthesis pathway associated with warmer climates, decreases northward as average minimum temperatures during the growing season decline. ${ }^{16}$ Overshadowing the north-to-south gradient and coinciding with the subdivision of the grassland region into short grass steppe, mixed grass prairie, and tall grass prairie is the increase from west to east of available moisture for plant growth.

Short Grass Steppe. In westernmost sections of the midcontinent, the dominant natural vegetation is grasses that are generally 20 to 50 centimeters high. Blue grama and buffalo grass dominate, but western wheat grass, needle-andthread grass, and wire grass are also important. These grasses are timed to grow with the spring rains. Most go dormant in summer to avoid the stresses of depleted soil moisture. Borchert has shown that "the short grass region is climatically distinctive in most summers." 17 A steep gradient in warm season rainfall is a characteristic 
of the midcontinent; precipitation totals decrease rapidly westward from the 100 th meridian.

The short grass steppe may have evolved in response to grazing pressure from the native ungulates including bison, pronghorn, and wapiti, or elk. Because animals generally graze grass species to the same level, the shoots of taller grasses are more susceptible. Their lowness and the focus of their growth on root production means the short grasses may suffer comparatively less from grazing than do taller species. Shorter grasses can also tolerate years of below normal rainfall better than tall grasses can. Thus, both climate and a disturbance factor, grazing, helped reinforce short grasses as the dominant cover.

Mixed Grass Prairie. Geographically located between the tall grass prairies to the east and the short grass steppes to the west, the area of mixed grass vegetative cover has been considered by some to be a transition zone or ecotone, in part because it contains species present in both the short and tall grass areas. Short grasses, such as blue grama and buffalo grass, occupy a lower layer, while the midgrasses, little bluestem, needle-and-thread grass, side-oats grama, and western wheat grass, penetrate above this level to heights of approximately 125 centimeters, imparting a distinctive structure to the mixed grass region.

Boundaries between the mixed grass prairie and the neighboring grassland vegetation types are indistinct. A line corresponding to the twenty-inch annual precipitation isohyet has been used to define the eastern margin of the mixed grass prairies, but other generalized boundary locations include the $97^{\circ} \mathrm{W}$ meridian and the 1500-foot elevation contour. Küchler has shown that the location of the mixed grass prairie in Kansas shifts eastward in dry years and westward in wet. These are not species migrations but changes in species dominance within the boundary areas. Effects of these changes in dominant species are most striking in the border zones between the major grassland vegetation types. ${ }^{18}$

Müller and Weaver found that the seedlings of plants characteristic of uplands or western areas resisted drought better than did the tall grass or lowland prairie species. When available moisture exceeds a threshold value, the growth of a plant above the ground is directly proportional to annual water use. Thus plant populations within the mixed grass prairie fluctuate dramatically in response to climatic variations. Comparison of climate factors to vegetation types shows that the mixed grass prairie coincides with a region receiving 50 percent or less of normal rainfall during July of major drought years. ${ }^{19}$

Tall Grass Prairie. Grasses that can grow more than two meters high characterize this region. Tall grass prairie is not only taller but also has the greatest species diversity of the three grassland types. Dominants include big bluestem, Indian grass, and switch grass, but on drier upland sites little bluestem, needlegrass, Junegrass, prairie dropseed, and side-oats grama are common. In fact a hillside may replicate the east-to-west groupings of grasses from top to bottom, with the taller grasses in the moister lowland soils and the shorter ones in the drier soils near the hilltop. ${ }^{20}$ Thus moisture availability regulates the plant populations of midcontinent grasslands on both local and regional scales.

Prior to Euro-American settlement of the midcontinent, the Prairie Peninsula extended eastward across Iowa, Illinois, Indiana, and into Ohio. The origin of this tall grass peninsula has been the subject of considerable debate, centered primarily on the combined or separate roles of climate and fire within the region. What caused these prairies? Numerous authors have argued that the Prairie Peninsula is a fire-maintained grassland in an area of forest climate, whereas those scientists who have examined regional climatic data and presented the results of their studies have concluded that the Prairie Peninsula has a climate that differs significantly from that of adjacent forest areas. ${ }^{21}$ As with most disagreements, a perspective that integrates both sides of the argument will probably emerge. Theorists are now, however, beginning to recognize fire as a natural environmental component of the tall grass prairie as well as most other midcontinent ecosystems. ${ }^{22}$ 
The Forests: The Prairie-Forest Ecotone. Two distinct vegetation types, riparian forests and oak savannas, make up the transitional zone separating the midcontinent grasslands from eastern areas of nearly continuous forest cover. Flood plain, gallery, or riparian forests were found penetrating into the grassland region along most major stream courses. Able to tap a river's abundant local ground water supply, these forests were somewhat immune to the major midcontinent droughts. Cottonwoods, willows, elms, and ashes, their seedlings germinating during spring flooding, are the dominant trees of these riparian areas where site conditions moderate an environment otherwise inimical to trees.

The upland prairie-forest ecotone is usually characterized by park-like vegetation of oaks and prairie grasses. The best examples of this savanna vegetation were found in belts 75 to 175 kilometers wide in the "Cross-Timbers" areas of Oklahoma and Texas and in "oak openings" in Minnesota and Wisconsin. ${ }^{23}$ Burr oak dominated the northern savannas and post and blackjack oaks the tree strata of the Cross-Timbers. Frequent burning that destroyed other trees was necessary to maintain oak savannas. Their fire-resistant bark allowed the older, larger oaks to survive the frequent fires, and coppicing from surviving roots of burnt younger trees quickly reestablished the oak community, while less firetolerant trees, such as green ash in the north, succumbed to the fire. In addition, the roots of oak seedlings grow very rapidly, allowing pioneer oak species to compete successfully with grasses for limited available moisture. ${ }^{24}$

The Deciduous Forests. The midcontinent deciduous forests are divided into six major units according to composition and environment. Passing through increasingly cooler and wetter conditions from the grasslands toward the north and east, one finds forests of the Oak-Hickory Association, the Maple-Basswood Association, and the Hemlock-White Pine-Northern Hardwoods Association. Toward the wetter and warmer east and south, the Oak-Hickory Association gives way to the Oak-Pine Association and then to the Southern Mixed Hardwood As- sociation. The sixth unit, the Flood Plain Forests, occupy areas subject to periodic flooding. In each unit the success of the dominant species reflects environmental conditions.

Oak-Hickory Association. Oak forests with varying amounts of hickory are found on the driest sites within the westernmost sections of deciduous forests in Minnesota, Wisconsin, Illinois, Missouri, Oklahoma, and Texas, where they are commonly subjected to late summer drought. Locally such forests may be found on hilltops, ridges, slopes with south or west exposures, and areas of thin soils. Emergent oak seedlings survive in this xeric habitat because they can obtain soil moisture through rapid root extension following spring germination. ${ }^{25}$ Oak seedlings are not as dependent on current photosynthetic production as other tree seedlings because they tap stored carbohydrates in the acorn during periods of limited soil moisture.

In general, the number of species within oakhickory forests declines toward the west. ${ }^{26}$ Dominant oaks, in addition to the species of the savannas, include white, southern red, northern red, and black oak. The hickories, bitternut, mockernut, red, black, and shagbark, are found with increasing frequency in areas to the east. Oak-hickory forests have the greatest species diversity in the Ozark Mountains of northern Arkansas and southern Missouri.

Maple-Basswood Association. Deciduous forests of sugar maple, American basswood, and American elm occur on relatively moist upland sites to the north and east of the prairie-forest ecotone. A mosaic of oak-hickory and maplebasswood forest types exists across sections of Minnesota and Wisconsin in response to variations in soil texture. Grimm indicates that the probability of fire at individual sites, a reflection of soil texture and moisture conditions, is an important factor controlling the distribution of maple-basswood forests. ${ }^{27}$

Both seedling growth and nutrient cycling characteristics help differentiate the maplebasswood and oak-hickory forests. Sugar maple seedlings use stored carbohydrate for early spring growth, but later require current year photosynthetic production, disadvantaging maples 
relative to oaks during a summer dry period. Nutrient cycling also helps to distinguish oak and maple forests. Nutrients that remain in sugar maple leaves when the leaves fall are transferred to the soil. Thus maple-basswood forest soils are more fertile than oak-hickory forest soils in part because oaks store nutrients in their trunks during the cool season period of dormancy rather than returning them to the soil. ${ }^{28}$

Hemlock-White Pine-Northern Hardwoods Association. Areas of mixed coniferous-deciduous forest extend from northeastern Minnesota eastward through the Great Lakes region to the Atlantic Ocean. Within these forests, water is the single most important ecological factor and its relative plenitude determines the variations in the association. ${ }^{29}$ Primary subdivisions include bog or swamp forest on organic soils, the "pineries" on the drier, sandy soils, and upland mesophytic forests consisting of a mixture of coniferous and deciduous species on finer textured soils. The addition of cone-bearing, evergreen trees to the deciduous species helps differentiate this forest association and also indicates a transition to cooler and moister environments.

Oak-Pine Association. In the southeastern midcontinent, particularly in southern Arkansas and parts of east Texas, southern pines add a similar coniferous element to deciduous forests. Some scientists consider the areas of southern shortleaf and loblolly pines to be a fireproduced subtype of the oak-hickory forest, but others recognize the relative dominance of the pines in areas of coarse textured, infertile soils, or south-facing slopes. ${ }^{30}$ Oak-pine forests occur in areas that receive an average of forty or more inches of rainfall annually, well to the south and east of the prairie-forest ecotone. Fire is necessary for maintenance of the pine component within these forests because it removes understory competition and prepares a mineral seedbed for subsequent pine establishment, but local variations in environment also account for the existence of this forest association.

Flood Plain Forests. Flood plains, bottomlands, and glacial lake plains subject to periodic flooding support forested wetlands well fertilized by silt. Hardwood swamp communities tolerate wet, poorly aerated soil. Northern flood plain forests are similar in composition to the riparian forests that extend westward into grassland areas, but in the southern flood plain forests oaks, tupelos, and bald cypress are the usual dominants of seasonally flooded sites.

\section{Human Alterations}

Few sites remain where the natural vegetative cover of the midcontinent has been preserved from human alteration. Disturbance and change are natural parts of all ecosystems, but the pronounced effects of human activity can be seen in almost every tract of land in the midcontinent. Substantial and long-lasting changes in the vegetative cover accompanied the westward expansion of European settlement across the United States. Native Indians had also altered the environment, but their impact was minor compared to Euro-American practices of plowing and clear cutting.

Different vegetation types underwent different types of environmental alteration, but each area is now adjusting to new cycles of nutrient and energy flow and possibly to new equilibrium states. The most obvious and direct environmental changes in the midcontinent are logging, plowing, introduction of new fire regimes, and alterations in grazing pressures. In addition virtually all of this area is currently subjected to the indirect and controversial effects of acid rain and increased levels of atmospheric $\mathrm{CO}_{2}$.

Logging, either clear cutting or selective harvesting of specific tree species, has greatly altered the forested areas of the midcontinent. In most areas, today's forests have grown back recently after human disturbance. These second growth forests represent the vegetative response to forest clearing for agriculture and to clear cutting of selective species, such as white pine in the north or loblolly pine in the south. In many cases, both the composition and structure of today's forests are markedly different from those of several hundred years ago.

Fire is a natural element in all midcontinent ecosystems. Prior to western settlement, fires 
set by lightning or by native Indians characterized both grassland and forest. In most areas, Euro-American settlement has reduced fire frequency, but where fire suppression efforts and unwise logging practices allowed fuel loads to build, severe slash and crown fires resulted. In the oak savannas, fire suppression has allowed the oaks to fill in the openings, destroying the park-like character of this vegetation type. Burning is also necessary to many prairie grassland ecosystems. Fire suppression has led to a woody plant invasion, particularly along the forest margins. Today, controlled burning is used to restore and maintain prairie grassland.

Plowing has also altered the midcontinent. Beginning in the 1830s farmers equipped with steel moldboard plows turned the sod on the overwhelming majority of the tall grass prairie. Much of this area is farmed today, but in abandoned fields near the prairie-forest ecotone, tree cover has followed the plow, encroaching into former prairie areas where fire suppression has protected it. Plowing also affected areas of original deciduous forests. Most of today's deciduous forests in the midcontinent have gone through a cycle of logging, plowing, abandonment, and old-field succession before eventually regaining a forest cover. These wooded areas resemble the prehistoric forests to varying degrees depending upon the extent and frequency of disturbance as well as the makeup of the original forest. ${ }^{31}$

Grazing is both a natural component and a human induced alteration of midcontinent ecosystems. Deer, bison, and other native animals fed on the vegetation of both forests and grasslands. Overgrazing is brought about by an increased number of grazing animals and by fencing that restricts animals to specific tracts of land. The main vegetative response to grazing pressure is a change in composition. Decreaser species become less important as increasers gain in relative dominance while invaders enter the site.

The present vegetative cover of the midcontinent provides some evidence of presettlement conditions, but it bears direct testimony to the powerful influences of human alteration. Despite the efforts of Euro-American settlers to change the landscape to suit their economic goals, however, the overriding imprint of natural environmental controls remains. Gross patterns of ranching, agriculture, and forest activity are clearly arranged in association with climatic gradients of temperature and available moisture.

\section{NOTES}

1. A. W. Küchler, "Oscillations of the Mixed Grass Prairie in Kansas," Erkunde 26 (1972): 12029.

2. E. Palmén and C. W. Newton, Atmospheric Circulation Systems (New York: Academic Press, 1969).

3. J. R. Harman and D. H. Braud, "Flow Patterns at the $500 \mathrm{mb}$ Level and the Prairie-Forest Ecotone in Canada," Michigan Academician 7 (1975): 347-56; J. A. Harrington, Jr. and J. R. Harman, "A Synoptic Climatology of Moisture Stress Gradients in the Western Great Lakes Region," Physical Geography 6 (1985): 43-56.

4. R. A. Bryson, "Air Masses, Streamlines, and the Boreal Forest," Geographical Bulletin 8 (1966): 228-69; W. M. Wendland and R. A. Bryson, "Northern Hemisphere Airstream Regions," Monthly Weather Review, 109 (1981): 255-70.

5. W. T. Corcoran, "Moisture Stress, Mid-tropospheric Pressure Patterns, and the Forest/Grassland Transition in the South Central States," Physical Geography 3 (1982): 148-59.

6. J. R. Borchert, "The Climate of the Central North American Grassland," Annals of the Association of American Geographers 40 (1950): 1-39; D. D. Collins, "Macroclimate and the Grassland System," in R. L. Dix, ed., The Grassland Ecosystem, A Preliminary Synthesis (Fort Collins, Colorado: Range Science Department Science Series, No. 2, 1969), pp. 29-39; F. K. Hare, "Some Climatological Problems of the Arctic and Sub-Arctic," in T. F. Malone, ed., Compendium of Meteorology (Boston: American Meteorological Society, 1951), pp. 952-64; H. A. Gleason, "The Vegetational History of the Middle West," Annals of the Association of American Geographers 12 (1923): 39-85; R. F. Neilson et al., Sensitivity of Ecological Landscapes and Regions to Global Climatic Change (Corvallis, Oregon: US EPA, Environmental Research Laboratory, 1989), quoted p. 21.

7. E. N. Transeau, "The Prairie Peninsula," Ecology 16 (1935): 423-37.

8. E. N. Transeau, "Forest Centers of Eastern America," American Naturalist 39 (1905): 875-89.

9. Transeau, "Prairie Peninsula" (note 7 above), pp. 423-37; quoted p. 428.

10. Borchert, "Climate of the American Grassland" (note 6 above); J. R. Mather, "The Moisture Balance in Grassland Climatology," in H. B. Sprague, 
ed., Grasslands (Washington: American Association for the Advancement of Science Publication 53, 1959), pp. 251-61; C. Manogaran, "The Prairie Peninsula: A Climatic Perspective," Physical Geography 4 (1983): 153-66.

11. J. E. Basu, "Jerome Namias: Pioneering the Science of Forecasting," Weatherwise 37 (No. 4, 1984): 191-94, 199-201; R. P. Neilson, "High-Resolution Climatic Analysis and Southwest Biogeography," Science 232 (1986): 27-34.

12. Borchert, "Climate of the American Grassland" (note 6 above); Bryson, "Air Masses, Streamlines, and Forest" (note 4 above).

13. Harrington and Harman, "Climatology of Moisture Stress Gradients" (note 3 above); J. A. Harrington, Jr., "Upper Atmospheric Controls, Surface Climate, and Phytogeographical Implications in the Western Great Lakes Region," Ph.D. Diss., Michigan State University, 1980; Corcoran, "Moisture Stress and the Forest/Grassland Transition" (note 5 above).

14. M. B. Davis, "Pleistocene Biogeography of Temperate Deciduous Forests," Geoscience and Man 13 (1976): 13-26; J. C. Bernabo and T. Webb, III, "Changing Patterns in the Holocene Pollen Record of Northeastern North America," Quaternary Research 8 (1977): 64-96.

15. D. A. Brown and P. J. Gersmehl, "Migration Models for Grasses in the American Midcontinent," Annals of the Association of American Geographers 75 (1985): 383-94.

16. J. A. Teeri and L. G. Stowe, "Climatic Patterns and the Distribution of $\mathrm{C}_{4}$ Grasses in North America," Oecologia 23 (1976): 1-12.

17. Borchert, "Climate of the American Grassland" (note 6 above), p. 6.

18. J. E. Weaver and F. W. Albertson, Grasslands of the Great Plains: Their Nature and Use (Lincoln, Nebraska: Johnsen Pub. Co., 1956); Küchler, "Mixed Grass Prairie" (note 1 above).

19. I. M. Müller and J. E. Weaver, "Relative Drought Resistance of Seedlings of Dominant Prairie Grasses," Ecology 23 (1942): 387-98; W. Webb et al., "Primary Productivity and Water Use in Native Forest, Grassland, and Desert Ecosystems," Ecology 59 (1978): 1239-47; R. T. Coupland, "The Effects of Fluctuations in Weather Upon the Grasslands of the Great Plains," Botanical Review 24 (1958): 273. 317; Borchert, "Climate of the American Grassland" (note 6 above).

20. J. E. Weaver, North American Prairie (Lincoln, Nebraska: Johnsen Pub. Co., 1954).
21. See Transeau, "Prairie Peninsula" (note 7 above); Borchert, "Climate of the American Grassland" (note 6 above); and Manogaran, "Prairie Peninsula: Climatic Perspective" (note 10 above).

22. O. L. Loucks, "Evolution of Diversity, Efficiency, and Community Stability," American Zoologist 10 (1970): 17-25; W. J. Parton and P. G. Risser, "Simulated Impact of Management Practices Upon the Tallgrass Prairie," in N. French, ed., Perspectives in Grassland Ecology, Ecological Studies 32 (New York: Springer-Verlag, 1979), pp. 135-55; T. R. Vale, Plants and People: Vegetation Change in North America, Resource Publications in Geography, Washington: Association of American Geographers, 1982).

23. J. L. Vankat, The Natural Vegetation of North America (New York: John Wiley \& Sons, 1979).

24. G. Cottam, "The Phytosociology of an Oak Woods in Southwestern Wisconsin," Ecology 30 (1949): 271-87; A. E. Holch, "Development of Roots and Shoots of Certain Deciduous Tree Seedlings in Different Forest Sites," Ecology 12 (1931): 259-98.

25. J. T. Curtis, The Vegetation of Wisconsin (Madison: University of Wisconsin Press, 1959); W. K. Ferrell, "Effect of Environmental Conditions on Survival and Growth of Forest Tree Seedlings under Field Conditions in the Piedmont Region of North Carolina," Ecology 34 (1953): 667-88.

26. E. L. Braun, Deciduous Forests of Eastern North America (Philadelphia: Blankiston, 1950).

27. Ibid., pp. 327-36; E. C. Grimm, "Fire and Other Factors Controlling the Big Woods Vegetation of Minnesota in the Mid-Nineteenth Century," Ecological Monographs 54 (1984): 291-311.

28. T. T. Kozlowski and R. C. Ward, "Seasonal Height Growth of Deciduous Trees," Forest Science 3 (1957): 168-74; Curtis, "Vegetation of Wisconsin" (note 25 above).

29. G. E. Nichols, "The Hemlock-White PineNorthern Hardwood Region of Eastern North America," Ecology 16 (1935): 403-22; H. C. Cowles, "The Physiographic Ecology of Northern Michigan," Science 39 (1900): 708-9.

30. Vankat, Natural Vegetation of North America (note 23 above).

31. S. L. Dodge and J. R. Harman, "Woodlot Composition and Successional Trends in Southcentral Lower Michigan," Michigan Botanist 24 (1985): 43-54.

32. A. W. Küchler, Potential Natural Vegetation of the Conterminous United States, Special Publication 36 (New York: American Geographical Society, 1964). 